\title{
Doing what's necessary
}

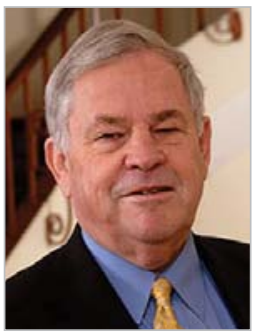

Stephen Leeder Editor-in-Chief mja@mja.com.au

doi: 10.5694/mjal4.c0915 social response is preferable. This is a hard lesson, akin to not pursuing hero-knight responses to complex international problems, where war looks attractive in assuaging our frustrations. Seeking diplomatic resolutions is often the dull but effective alternative.

Above and beyond the challenges of immediate clinical practice, including caring for people with drug problems, are global health disasters that are often associated with poverty, the disrupted world of war, appalling power politics and exploitation. In times past, these factors combined to create a social Petri dish in which ghastly infections found nourishment. And not just in times past - the current Ebola virus epidemic in West Africa, the subject of two articles in this issue and an accompanying podcast with Sorrell and Hill-Cawthorne, is nurtured by poverty. In the first of these articles, Banerjee and colleagues (page 320) outline the essentials of the outbreak and Australia's response and public health preparedness.

As pointed out in the 16 August edition of The Economist (http://www.economist.com/news/ international/21612157-spread-ebola-west-africadeeply-troubling-region-and-world-fever), the current Ebola epidemic began in three of the world's poorest

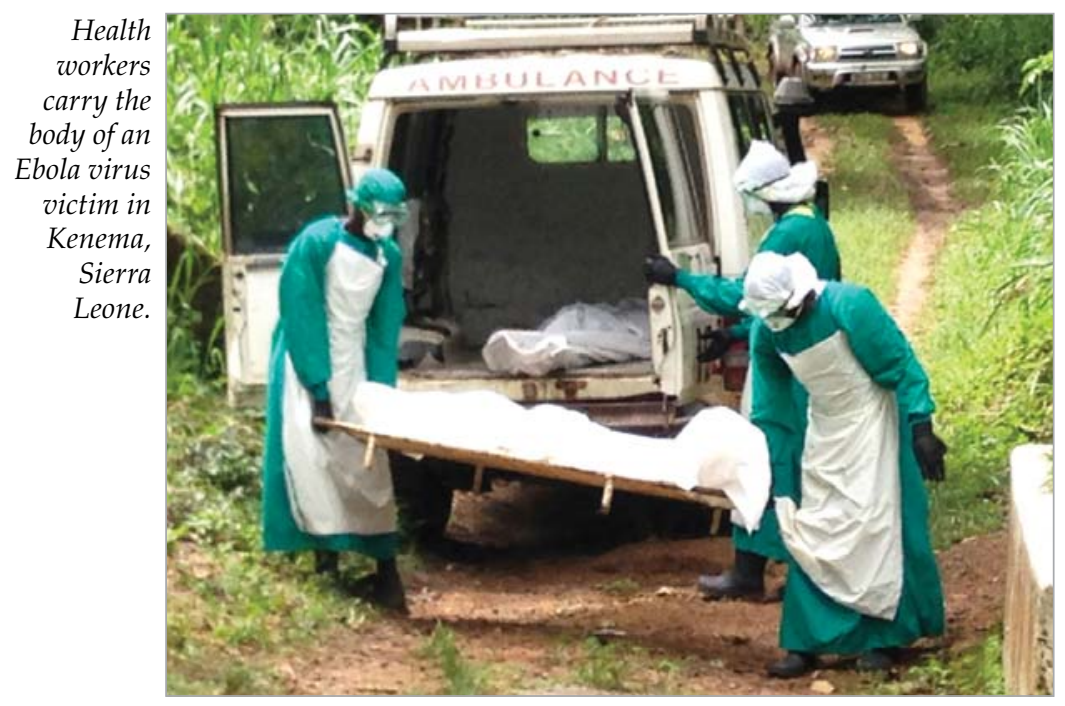

Umaru Fofana/Reuters

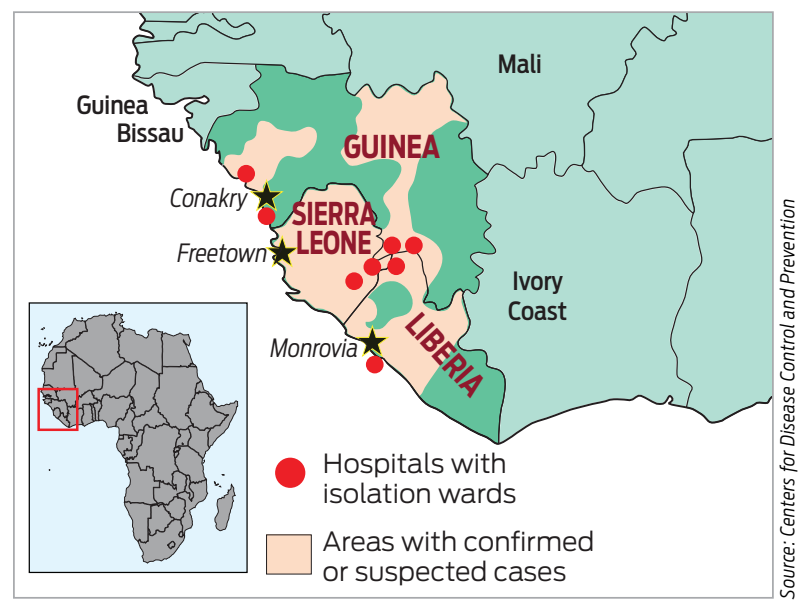

countries - Guinea, Liberia and Sierra Leone. “Guinea spends $\$ 62$ per person on health each year [compared with $\$ 3970$ in Australia]. Sierra Leone has two doctors per 100000 people [compared with 327 in Australia]". The social economic environment in which Ebola is transacting its business in these countries and the ethical problems this raises are the subject of the article by Hooker and colleagues (page 352). They argue that the impact of Ebola virus in West Africa is exacerbated by market-driven resource misallocation that quarantines needed therapeutics in rich countries, where global health interests are subservient to biosecurity agendas. They also claim that austerity programs imposed by global financial bodies have led to health infrastructure running down in vulnerable countries. Greenberg (page 315), a Manhattan epidemiologist and cardiologist with a passion for prevention of cardiovascular disease in developing countries, explores the three principal eras of global health assistance, of which preventing noncommunicable disease is the third. But at any time we can regress to the age of infectious disease if the social circumstances permit.

Ebola reminds us not only about the potency of infections but also more profoundly of the residual task that challenges all of us who have a humane concern for the plight of those still trapped in poverty. In a recent conversation I had with a health student in Sydney from Sierra Leone, I learned of the lack of toiletries, bedclothes and basic supplies, including cups to drink rehydration fluid, for Ebola patients in the hospitals. The medical and nursing staff are dying exhausted and infected.

One great virtue of being a clinician is that there is plenty at hand to do that can yield a rich dividend. That can be empowering. Clinical achievements permit us to frame the massive problems of the world in a different way. St Francis of Assisi advised: "Start by doing what's necessary; then do what's possible; and suddenly you are doing the impossible". 